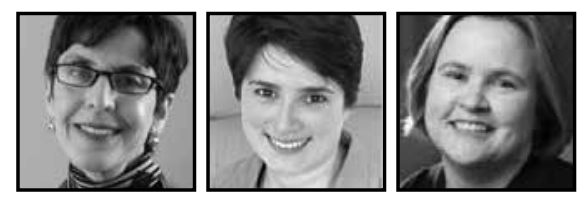

\title{
More Than Hoop Jumping: Making Accreditation Matter
}

\author{
Mary D. Burbank, University of Utah \\ Melissa M. Goldsmith, University of Utah \\ Alisa Bates, Concordia University
}

\begin{abstract}
This study provides a discussion of faculty perspectives on the impact of national accreditation on a teacher education program. Research questions from a three-year investigation examined the influence of accreditation on how teacher educators approach their work and whether meeting accreditation requirements contributes to ongoing, systemic self-reflection. Self-study survey data identified faculty perspectives on the influence of accreditation on planning, instruction, curriculum development, assessment, collaboration, reflection, and awareness of accreditation discussions. Accreditation as a form of self-study reveals both strengths and the inherent challenges of meeting the sometimes competing goals of accreditation requirements and meaningful examinations through self-reflection. Study implications underscore the need for conscious efforts to maintain self-reflection as central to program improvements and considerations for teacher educators' work.
\end{abstract}

n today's education climate, rarely a week passes when the status of education or its constituent parts are not critiqued, including curriculum choices, student performance, teacher preparation, and performance reporting. Subsequent conversations among stakeholders cast blame on any number of reasons for why the profession is seen as needing a fundamental overhaul due to its perceived inadequacy, subpar international standing, and presumed broken status (Duncan, 2009; Felch, Song, \& Smith, 2010; National Council on Teacher Quality, 2013). 
As conduits to K-12 student learning, teacher education programs are also reminded of their role, often through indictments on the quality of K-12 teacher preparation (Finn, 2001; Laberee, 2004; Maier, 2012; National Council on Teacher Quality, 2013). New takes on accreditation, "blueprints" for success in program development, and think tanks are among the remedies proposed (United States Department of Education, 2013). Regardless of the stakeholder, calls to define quality insist on data to fortify excellence while simultaneously engendering what some propose as healthy competition in teacher preparation (Hess, 2001; National Council on Teacher Quality, 2011, 2013; Zeichner, 2007). Defining the characteristics of "quality" and agreeing on what constitutes "data" are areas of program evaluation open to varied perspectives.

This study provides a discussion of a teacher education faculty's perspectives on the impact of national accreditation on their reflective practices about quality teacher education. Research questions examined the influence of accreditation on how teacher educators approach their work and whether meeting accreditation requirements contributes to ongoing, systemic self-reflection. Study findings identified the influence of accreditation on planning, instruction, curriculum development, assessment, collaboration, reflection, and awareness of accreditation discussions. Accreditation as a potential form of self-study reveals both strengths and the inherent challenges of meeting the sometimes competing goals of accreditation requirements and meaningful examinations through self-reflection. The implications underscore the need for conscious efforts to maintain self-reflection as central to program improvements and considerations for teacher educators' work.

\section{Introduction}

\section{Defining Quality}

Like the public education system, higher education faces the opportunity and the challenge of responding to newly defined evaluation structures that delineate broad-based goals for teacher preparation (Dillon \& Silva, 2011; Raths \& Lyman, 2003; Teaching Commission, 2006). Drawing from edicts that were sparked originally by NCLB (2001) and more recently through national evaluations of quality (e.g., National Council on Teacher Quality, 2013), prescriptions for producing "highly qualified" teachers are relying on teacher training programs to include increased rigor in course work, improved professional development for inservice teachers, and higher standards through competency testing (Hardy, 2002). Central to these efforts is the presumed merit of accreditation as the vehicle for evaluating the quality of teacher preparation and a direct connection to K-12 student performance. 
Theoretically, accreditation provides tools for data gathering and report development that chronicle teacher and student performance (Darling-Hammond, Amrein-Beardsley, Haertel, \& Rothstein, 2012). What is less clear is whether the accreditation process impacts systemic and sustained individual and collective reflections among teacher educators. Without an examination of the reflective potential of accreditation as a form of self-study, accreditation remains an exercise in hoop jumping that is reluctantly engaged by some and vigorously avoided by others.

\section{Accreditation and Self-Reflection}

\section{History of Self-Study}

The concept of self-study in teacher education is not new (e.g., Hamilton, 1992; Loughran, 1996; Russell \& Munby, 1992). Educational researchers and practitioners have long engaged in the process of self-study as a vehicle for examinations and reflection on practice (Cochran-Smith, 2005; Gore \& Zeichner, 1991; Loughran, 1996, 2002). A central dimension of self-study is a process of reflection and inquiry that is shared collectively, is public, and allows for reframing (Samaras \& Freese, 2009). Without a dedicated focus that allows for a critique and subsequent response, self-studies may be adopted in the same manner as any other "skill" for technique-based examinations of practice.

Beyond skill development, the reflective component of self-study is also a process in its own right that allows for in-depth examinations of practice over time (Dinkelman, 2003). Dinkelman (2003) contends that as a true form of self-reflection, self-studies must also contribute to how we consider questions about teachers' work (teacher educators included), serve as a model for students, and prompt programmatic change through analyses of the kinds of knowledge produced that reflect in-depth reviews over time. Critically reflective practices are essential in this process.

\section{Reflection}

Critically reflective thinking and critical reflection have been long been defined in a variety of ways in teacher education research (Brookfield, 1995, 2009; Larrivee, 2000; Rodgers, 2002). The process often includes dilemma identification or problem framing from multiple perspectives that include critical examinations of practice both individually and system-wide. Regardless of the focal areas (i.e., individual or institutional practice), the process occurs by questioning and analyzing takenfor-granted assumptions, routines, rationalizations, and unexamined explanations (Carrington \& Selva, 2008; Loughran, 2002; Rodgers, 2002; Shandomo, 2010). 
Historically, examinations of reflective thinking offer perspectives on the individual and how he or she thinks as well as the process of problem solving (Dewey, 1933; Schön, 1983). Dewey's (1933) and Schön's (1983) conceptions of reflective thinking focus on multiple-perspective problem framing where all available data are used to seek and evaluate solutions. Although Schön's view of reflection includes a change component, these conceptions are not necessarily critical in the political sense of the word. Others have emphasized that to be critical, results must transform curricula and practice, focus on criteria of equity and justice, or alter the status quo (cf. Van Manen, 1977; Brookfield, 1995; Fook, 2006). Brookfield (2009) contends that the addition of "critical" represents a shift from working within an existing system toward questioning the system, assessing it, and considering alternatives. Without a commitment to examinations that push beyond the norm, "reflections" remain narrow and insulated.

\section{More Than Bean Counting}

A challenge for teacher educators who are committed to systemic program reform involves a movement away from data collection and data mining for the sole purpose of responding to accreditation mandates. Alternatively, deliberate question posing and problem identification must be a part of the process of self-study. Critically reflective problem solving, for example, is conceptualized as framing and reframing problems from multiple perspectives, generating and evaluating a range of possible solutions, and considering the personal, academic, political, and ethical consequences of solutions for students and society (Gore \& Zeichner, 1991; Leland, Harste, \& Youssef, 1997; Rodgers, 2002; Zeichner \& Liston, 1996).

Critically reflective problem solving is thought to benefit both teachers and students by widening teachers' "understanding of teaching beyond narrow technical concerns to the broader socio-political influences" that affect students' learning (Risko, Roskos, \& Vukelich, 1999, p. 113). The challenge for those engaged in self-studies linked to accreditation is a dedicated commitment to exceeding the technical requirements of program improvement. Instead, a more critical lens is necessary both in problem and question identification as well as in how data are reviewed and used, thereby affording opportunities for critically reflective thinking.

The more traditional approach to program evaluation, at times, dictates and justifies why program studies take place; program evaluation efforts are often lacking the more lasting and introspective dimension of true self-studies. The dilemma for teacher educators is steeped in tensions where self-studies are driven by outcomesbased goals that include a checklist mentality for program evaluations requirements. 
This outcomes-based approach stems from a focus on the means to accomplishing a particular goal efficiently and effectively, without examining the goal itself and its underlying values and assumptions (Valli, 1993). Even when efforts are made to look beyond standardized performance assessment, teacher educators must be cautious in their intentions for data collection and data use. On a larger scale, data generated as part of self-studies have the potential to contribute to professional literature in ways that enhance teacher education (Zeichner, 2006).

The present study identified how the process of self-reflection, prompted by and affiliated with accreditation, was perceived by educators within a nationally accredited teacher education program. This study captures faculty reflections on: program goals and mission claims, reliability and validity in program assessment, and determining how "quality" is formalized. Findings reveal both genuine value in the process of accreditation as a prompt for self-study, as well as challenges of participation in ongoing self-studies that are rooted in accreditation frameworks.

\section{Methods}

\section{Research Objectives}

Influenced by the role of self-study as a method for critical reflection on practice, this research examined self-study survey data from 22 faculty members in "Western University's" teacher education program. Research questions included: What are the perspectives of faculty in a teacher education program on the process of accreditation? How does the process of accreditation impact the daily work of program faculty? What do faculty members perceive to be the strengths and limitations of engaging in accreditation? The survey questions were crafted to measure key areas of an educational program self-study including planning, instruction, curriculum development, assessment, collaboration, reflection, and awareness of accreditation discussions. Faculty perceptions regarding accreditation varied in depth and intensity.

\section{Data Sources and Collection}

\section{Participants}

Following 2011 accreditation approval by the Teacher Education Accreditation Council (TEAC), a survey was distributed to teacher licensure faculty at Western 
University. Data were collected at three yearly intervals between 2012 and 2014. The respondent pool for all waves of data collection included tenure-track and clinical licensure program faculty who had participated in the accreditation process. The same faculty members were asked to complete the surveys at multiple time intervals to determine changes in the group's attitudes and behaviors over time (Neuman, 2003).

Across all data collection periods, the majority of respondents were faculty from the Elementary, Secondary, and Special Education program options. In 2012 and 2013, approximately half of the respondents were tenure-track faculty members. In 2014, approximately two-thirds of the respondents were clinical faculty members. Between 2012 and 2014 response rates were reported at $77 \%$, 86\%, and $75 \%$ respectively.

\section{Data Collection}

Survey method for waves 1 and 2. The 2012 and 2013 surveys consisted of 17 questions where the majority asked faculty to complete online surveys where they rated questions using a five-point Likert scale of "strongly disagree," "somewhat disagree," "neither agree nor disagree," "somewhat agree," and "strongly agree." Faculty rated statements asking whether the national accreditation process affected the overall quality of students' preparation, faculty members' approaches to course work, teaching, curriculum, collaboration, reflection on their work, assessment, and confidence in measures of program assessment, and awareness of local and national conversations about accreditation. The surveys also asked respondents to indicate their department and rank (i.e., tenure-track or clinical faculty).

In addition to closed-ended questions, the surveys included five open-ended questions that prompted faculty to discuss whether the national accreditation process affected the quality of student preparation, their work, their students' classroom experiences, their approach to learning assessment, and their level of discussions with others about assessment. ${ }^{2}$

Survey method for wave 3. The 2014 survey, more narrow in scope than the previous two, addressed respondents' most recent experiences with specific accreditation-related efforts including: aligning rubrics across specialization areas, improving inter-observer reliability of student teaching episodes, and identifying student teaching portfolio artifacts and rubrics that were common across specialization areas (e.g., Elementary and Secondary education). Accreditation feedback prompted attention to these tasks. By years two and three, post-accreditation visit, faculty began to formalize the process 
of collaborating within and between specialization areas on these various program improvement areas. The survey included 16 questions where faculty considered a statement and rated it using the same five-point Likert scale as in previous surveys. Statements addressed whether accreditation efforts affected the overall quality of students' preparation, teaching practices, and their approach to supervision. As with previous survey waves, respondents indicated their department and faculty rank.

Several open-ended questions prompted greater specificity on whether the accreditation process affected the quality of student preparation; to what extent, if at all, the self-study component of accreditation was useful; in what ways, if any, accreditation efforts impacted views regarding teacher preparation; what, if anything, a faculty member learned about how other faculty members approach student teaching observations; and, in what ways, if any, the process of aligning rubrics and identifying work samples had been informative.

\section{Data Summary}

Survey data were analyzed for each year using frequency distributions and descriptive statistics. Where questions were the same from year to year, these data were examined for statistically significant differences between years using paired sample t-tests and Kolmogorov-Smirnov tests. Data were also analyzed on the subgroup level (i.e., tenure-track versus career-line faculty) using cross-tabulations and Chisquare tests. Correlations were used to determine relationships among key variables (Bohrnstedt \& Knoke, 1994).

Although there were no statistically significant year-to-year differences for the average response to any question, in some areas, the distribution of responses within a question changed from one year to the next. We also found that national accreditation affectedfacultysubgroups differently (e.g.,clinicalfacultymorethantenure-trackfaculty). Substantive findings demonstrate how the accreditation process framed a systematic and balanced approach to assessment and program study. Findings also showed that faculty are generally quite open to improvement and individualized reflection on practice. Many cited the advantages of using a common language for evaluating student progress, the merits of consistency in emphases across courses, and the utility of a formalized process for data-based decision making. For some, the primary goal of accreditation was to meet general administrative requirements governing program quality, while simultaneously gaining approval from an accreditation oversight body. 
For others, data collection prompted self-reflection on program improvement using a systematic template for building an organizational narrative.

\section{Impacts on Program Quality}

Within the survey, faculty members rated their level of agreement or disagreement on whether involvement in national accreditation impacted the overall quality of student preparation. During both 2012 and 2013, about half of faculty members reported the overall quality of students' preparation had improved as a result of the university's involvement in national accreditation. For individuals who responded positively to a potential relationship between national accreditation and student quality, benefits included greater awareness of state standards, inter-departmental collaboration, and increased support for students. One respondent who agreed that the overall quality of students' preparation has improved wrote, "The self- reflection and coordination required for the national accreditation is helpful in spurring additional thinking about processes, programs, and classes."

As more time had passed since the accreditation visit, faculty members who did not agree that the overall quality of students' preparation had improved as a result of the university's involvement in national accreditation became less ambivalent and more likely to have a distinct negative opinion about the connection between the university's involvement in national accreditation and its overall quality of students' preparation. When faculty were asked to rate the impact of accreditation on program quality, one 2012 respondent said, "I think the accreditation is [...] hoops to jump through that make no sense/don't improve the program."

\section{Impacts on Planning, Teaching, Assessment, Reflective Practices, and Discussion}

The survey asked faculty to consider the impacts of accreditation for key areas associated with a self-study, including coursework planning and assessment. For each area, at least some contingent of the faculty indicated that national accreditation had impacted their work. When asked to evaluate the impact of accreditation on coursework planning, nearly half of faculty respondents agreed that their approaches had changed as a result of accreditation requirements in the first two years after accreditation. When asked to evaluate the impact of accreditation on their approach to assessment, more than a third of respondents agreed that their approaches had changed as a result of accreditation requirements in the first two years after accreditation. Nearly half of faculty agreed that they have confidence in the measures used to assess program quality. 
The impact of national accreditation on faculty's teaching practices as well as curriculum development appeared to be a bit more complex. Approximately a third of faculty reported that their teaching practices were affected as a result of their involvement in national accreditation. An even larger percentage reported that their teaching practices were affected as a result of their work conducting specific accreditation-related tasks. However, most of the faculty who reported an impact of accreditation on teaching practices were clinical, rather than tenure-track faculty. One year after accreditation, clinical faculty were more likely than tenure-track faculty to report that their teaching practices had changed as a result of national accreditation. Three years after accreditation, this difference between clinical and tenure-track faculty was still present.

When faculty were asked to describe how their involvement in accreditation affected their students' classroom experiences, more were able to cite specific examples in 2013 than were able to in 2012. Cited examples included "be[ing] more transparent in my classes," "thoughtful application to the students' setting," and "some more time required on [the students'] part in relation to products for assessment." In year two, faculty members noted positive changes in the classroom as "students receive better quality," "more opportunities for hands-on experiences," and "more explicit and specific instruction on the standards of practice." However, faculty also noted some negative changes in the classroom, including an increasing burden on students to manage paperwork, stay current on evaluation forms, and submit portfolio assignments.

Nearly a third of faculty agreed that their involvement in national accreditation affected their approach to curriculum. Notably, the same distinction between clinical and tenure-track faculty that was present for teaching practices also existed when faculty reported on their approaches to curriculum. One year after the accreditation visit, clinical faculty were more likely than tenure-track faculty to say that their approaches to curriculum had changed as a result of their involvement in national accreditation.

In addition to considering the impact of accreditation on curriculum and instruction, faculty were also questioned about the impact of accreditation on their level of collaboration with colleagues, with about half of faculty members agreed that accreditation affected their level of collaboration with others. Collaboration was an area where the initial impacts of accreditation were apparent. ${ }^{3}$ Specifically, in 2012, self-study data indicated that collaboration, and no other study variables, was linked to faculty's attitudes regarding overall program quality. In 2013, overall quality rating was significantly correlated with all other variables including whether national accreditation affected faculty teaching practices, approaches to curriculum, collaboration, 
reflection on their work, approaches to assessment, confidence in measures, as well as participation in local and national conversations concerning accreditation. This yearto-year difference implies that as more time passed after the accreditation visit, faculty were more likely to recognize the accreditation process's widespread effects throughout the program.

Faculty reported that reflection on their work changed as a result of national accreditation. In both years, at least a third of faculty expressed that their reflective practices had changed as a result of accreditation. However, those faculty members who expressed ambivalence in 2012 expressed a stronger opinion (either negatively or positively) in how accreditation has impacted their reflective practices in 2013. Reflection was another area where opinions about the effect of national accreditation became more concrete for faculty as time passed.

About a third of faculty members agreed that their awareness of local and national conversations on accreditation has changed as a result of their participation in the accreditation process. In both instances, faculty members indicated that they were more initially plugged in to conversations about accreditation the first year after the accreditation visit than they were the second year after the visit.

Appendix A provides a summary of data themes from our findings.

\section{Conclusion}

Findings from this investigation demonstrate how standardization in teacher preparation does not have to be an end goal, as accreditation impacts faculty work differentially depending on the area of focus (e.g., teaching practices, assessment, etc.) and even when faculty hold different roles as tenure-track or clinical members of the program. Self-study data, originally driven by accreditation, revealed a series of findings highlighting both strengths and limitations of the process of meeting accreditation demands. The process of accreditation can affect faculty's work behaviors in a number of ways. Specifically, faculty members expressed that accreditation had an impact on student preparation, students' classroom experiences, and reflective practices as time passed from the accreditation visit. In these areas, faculty's initial expressions of ambivalence about whether accreditation impacted them in these areas in the first year turned into more well-defined opinions two years after the accreditation visit, indicating that faculty may not always know immediately how, if at all, their work will be affected 
by the accreditation process. In contrast, faculty felt that their level of collaboration with others and their awareness of local and national conversations about accreditation increased at once as a result of the accreditation process. The accreditation process affected clinical faculty more significantly than tenure-track faculty in the areas of teaching practices and curriculum development.

For some, the primary goal of accreditation is to meet general administrative requirements governing program quality, while simultaneously gaining approval from an accreditation oversight body. For others, data gathering and reviews for accreditation have lent themselves to wider conversations that would not have happened without the accreditation mandates. While these prompts are not universally accepted, discussions that exceed accreditation criteria are beginning to take place. Finally, the impact of discussions and reflections are both collective and collaborative; they highlight the process of reviewing one's work, build a sense of community, and make explicit the benefits gained and the potential pitfalls of the specific areas of study (Samaras \& Freese, 2009).

\section{Implications}

For others exploring whether the value of self-studies affiliated with accreditation helps faculty to view the process as more than hoop jumping, they are encouraged to define accreditation more broadly. Questions for consideration should encourage conscious efforts to reflect on the purposes of self-studies as well as the data gained from the process of self-studies. Obviously, many of the criteria affiliated with selfstudies meet the mandates for program documentation and evaluation. But for many institutions, perhaps an overlooked benefit of accreditation stems from more broad-based goals for quality and in-depth reflection on practice. However, without a systematic plan for moving beyond the "hoops" of accreditation, the mechanics of accreditation never move beyond data gathering and form completion. The following recommendations will guide others in their efforts to engage in systematic reflection that moves accreditation towards a meaningful process:

1. Framing problems: As with other forms of reflection, teacher educators must determine how they will frame self-studies in ways that meet their needs; must consider how problems were conceptualized and framed (or located); and must determine if multiple perspectives that are considered areas of study are formulated. 
2. Seeking solutions: What solutions were proposed, and how they will be related to the problems or suggested areas of evaluation?

3. Evaluating solutions: How are the data used to inform next steps for institutional and individual practices?

The answers to these questions are multi-layered and complex. Further, they also challenge the conventions of university, college, and departmental conversations that identify the purposes of teacher education and the value of various types of data collection on program quality. While self-studies lend themselves to data collection for problem solving and decision making, these outcomes are not the sole purposes of self-study. Nor, though, is self-study an end in and of itself. These lessons are particularly critical in the current climate with its emphasis on data collection for the purpose of defining and measuring performance.

At a time when teacher education is under intense scrutiny, teacher preparation programs must balance the realities of responding to accreditation requirements and reporting with the implementation of data-based decision making and broad-based self-reflection and program improvement. At times, these seemingly competing goals consume and drain the energy and resources spent showcasing data and its related impact on teacher preparation. Our findings revealed that the accreditation process heightened awareness by faculty of the need for systematic reviews of assessment tools, suggested more formalized plans for data collection and analysis, and challenged the need for an evidence-based program attuned to current practices in teacher education.

Without careful attention to moving beyond a process of filling in the blanks, an inherent feature of accreditation, efforts toward self-study as a continuous and reflective process remain unlikely. Feedback loops are encouraged and validated, however, without a deliberate commitment to efforts to move beyond the pendulum swings of a process-product view of engaging in self-study (Dinkelman, 2003), opportunities are lost for the benefits of self-reflection. The benefits of self-study as a continuous opportunity for review must be planned deliberately (Loughran \& Northfield, 2009).

When accreditation compliance broadly informs self-study efforts, participants are provided the freedom to learn from data through question posing and examinations of findings foster future data collection, program improvements, and reflection on practice. For colleges and universities preparing for accreditation, adopting a reflective approach to program improvement requires acceptance and participation in the 
process of critical examinations. At Western University, accreditation has positively affected the specific ways many faculty approach components of their work and their general satisfaction with program quality.

To be truly educative, self-studies affiliated with accreditation must require movement beyond a hyper-emphasis on the mechanics of evaluation in ways that detract from the fundamental mission of a teacher preparation program in unintended ways. As such, colleges of education must identify an approach that permits the faculty to balance program assessment with discussions of broader programmatic goals in ways that align with their missions, student needs, and research goals.

Without dedicated vigilance, accreditation remains an exercise in "hoop jumping." Conscious commitments to self-studies are catalysts for substantive conversations on teacher education. Data from this self-study indicate the process of accreditation offers both opportunities and potential barriers for program development and improvement and that, in some areas, opinion formation on the effects of accreditation takes time. As teacher educators, we are reminded that in the midst of the clamors for reform and an obsession with "drilling down" in data collection, self-reflection must underscore the complexity of teachers' work and the contexts in which they reside (e.g., Hargreaves, 2004; Sparks, 2004; Lasley, Siedentop, \& Yinger, 2006; Zeichner, 2006). These goals must remain foundational to quality teacher preparation.

\section{Notes}

1. In 2012 and 2013, the survey was sent out to 22 faculty members. In 2014 , the survey was sent out to 16 of these faculty members to capture the opinions of those who were involved in the specific accreditation tasks asked about in the survey. The response rates are calculated accordingly.

2. Due to a limited response in the first survey, "In what ways, if at all, have you participated in conversations about teacher education program assessment as a result of your involvement with national accreditation?" was not asked in the second survey.

3. For clarity, the question wording changed between years from "As a result of my involvement in national accreditation, collaboration with peers within my college changed," to "...collaboration with colleagues within my college has changed." 


\section{References}

Bohrnstedt, G. W., \& Knoke, D. (1994). Statistics for social data analysis (3rd edition). Itasca, IL: F.E. Peacock Publishers, Inc.

Brookfield, S. D. (1995). Becoming a critically reflective teacher. San Francisco: Jossey-Bass.

Brookfield, S. D. (2009). Critical reflection as an adult learning process. In N. Lyons (Ed.), Handbook of reflection and reflective inquiry (pp. 215-236). New York: Springer.

Carrington, F., \& Selva, G. (2008). Critical social theory and transformative learning: Evidence in pre-service teachers' service-learning reflection logs. Higher Education Research \& Development, 29(1), 45-57.

Cochran-Smith, M. (2005). Teacher educators as researchers: Multiple perspectives. Teaching and Teacher Education, 21(2), 219-225.

Darling-Hammond, L., Amrein-Beardsley, A., Haertel, E., \& Rothstein, J. (2012). Evaluating teacher evaluation. Phi Delta Kappan, 93(6), 8-15.

Dewey, J. (1933). How we think: A restatement of the relation of reflective thinking and the education process. Boston: D.C. Heath.

Dillon, E., \& Silva, E. (2011). Grading the teachers' teachers: Higher education comes under scrutiny. Phi Delta Kappan, 93(1), 54-61.

Dinkelman, T. (2003). Self-study in teacher education: A means and ends tool for promoting reflective teaching. Journal of Teacher Education, 54(6), 6-18.

Duncan, A. (October 22, 2009). U.S. Secretary of Education Arne Duncan Says Colleges of Education Must Improve for Reforms to Succeed. Retrieved from: http://www2.ed. gov/newspressreleases/2009/10/10222009a.

Felch, J., Song, J., \& Smith, D. (2010, August 14). Who's teaching L.A.'s kids? Retrieved from: http://www.latimes.com/news/local/la-meteachers-value-20100815,0,2695044.story

Finn, C. E. (2001). Getting better teachers-and treating them right. In T. Moe (Ed.), A primer on America's schools (pp. 127-150). Stanford, CA: Hoover Institution Press.
Fook, J. (2006, July). Beyond reflective practice: Reworking the "critical" in critical reflection. Keynote presented at the meeting of the Professional Lifelong Learning: Beyond Reflective Practice, University of Leeds, UK.

Gore, J., \& Zeichner, K. M. (1991). Action research and reflective teaching in preservice teacher education: A case study from the United States. Teaching and Teacher Education, 7(2), 119-136.

Hamilton, M. L. (1992). Making public the private voice of a teacher educator. Paper presented at the annual meeting of AERA. San Francisco, April.

Hardy, L. (2002). A new federal role. American School Board Journal, 189(9), 20-24.

Hargreaves, A. (2004). Broader purpose calls for higher understanding. Journal of Staff Development, 25(2), 46-50.

Hess, F. (2001). Tear down the wall: The case for a radical overhaul of teacher certification. Washington, DC: Progressive Quality Institute.

Laberee, D.F. (2004). The trouble with ed schools. New Haven, CT: Yale University Press.

Larrivee, B. (2000). Transforming teaching practice: Becoming a critically reflective teacher. Reflective Practice, 1(3), 293-307.

Lasley, T., Siedentop, D., \& Yinger, R. (2006). A systematic approach to enhancing teacher quality: The Ohio model. Journal of Teacher Education, 57(1), 13-21.

Leland, C. H., Harste, J. C., \& Youssef, O. (1997). Teacher education and critical literacy. In C. K. Kinzer, K. A. Hinchman, \& D. J. Leu (Eds.), Inquiries in literacy theory and practice: Forty-Sixth Yearbook of the National Reading Conference (pp. 385-396). Chicago: National Reading Conference.

Loughran, J. (1996). Developing reflective practice: Learning about teaching and learning through modeling. London: Falmer Press.

Loughran, J. (2002). Improving teacher education practice through self-study. New York: Routledge Falmer. 
Loughran, J., \& Northfield, J. (2009). A framework for the development of self-study practice. In Anja Swennen and Marcel van der Klink (Eds.) Becoming a teacher educator. Amsterdam: Netherlands: Swennen,Vrije Universiteit

Maier, A. (2012). Doing good and doing well: Credentialism for Teacher for America. Journal of Teacher Education, 63(1), 10-22.

National Council on Teacher Quality. (2011). State Teacher Policy Yearbook: National Summary. Retrieved from: http://www.nctq.org/stpy11 /reports/stpy11_national_report.pdf

National Council on Teacher Quality. (2013). US News and World Report. Retrieved from: http://www.usnews.com/education/nctq.

Neuman, W. L. (2003). Social research methods: qualitative and quantitative approaches (5th edition). Boston: Pearson Education, Inc.

No Child Left Behind Act of 2001. Public Law 107110 (8 January 2002). Washington, DC: U.S. Governance Printing Office.

Raths, J., \& Lyman, F. (2003). Summative evaluation of student teachers: An enduring problem. Journal of Teacher Education, 54(3), 206-216.

Risko, V., Roskos, K., \& Vukelich, C. (1999). Making connections: Preservice teachers' reflection processes and strategies. In T. Shanahan and F.V. Rodiguez-Brown (Eds.), Forty-eighth yearbook of the national reading conference yearbook. Chicago: National Reading Conference.

Rodgers, C. (2002). Defining reflection: Another look at John Dewey and reflective thinking. Teachers College Record, 104(4), 842-866.

Russell, T., \& Munby, H. (1992). Teachers and teaching: From classroom to reflection. London: Falmer Press.
Samaras. A., \& Freese, A. (2009). Looking back and looking forward. In C.A. Lassone, S. Glaman, and C. Cosnik (Eds.), Self-study research methodologies for teacher educators, (pp. 3-19). Boston: Sense Publishers.

Schön, D. A. (1983). The reflective practitioner. New York: Basic Books.

Shandomo, H. M. (2010). The role of critical reflection in teacher education. SchoolUniversity Partnerships, 4(1), 101-113.

Sparks, D. (2004). Broader purpose calls for higher understanding: An interview with Andy Hargreaves. Journal of Staff Development, 25(2), 46-50.

Teaching Commission. (2006). Teaching at Risk: Progress and Potholes. Retrieved from: www.theteachingcommission.org.

United States Department of Education. (2013). Blueprint for RESPECT (Recognizing Success, Professional Excellence, and Collaborative Teaching).

Valli, L. R. (1993). Reflective teacher education programs: An analysis of case studies. In J. Calderhead \& P. Gates (Eds.), Conceptualizing reflection in teacher development. London: Falmer.

Van Manen, M. (1977). Linking ways of knowing with ways of being practical. Curriculum Inquiry, 6(3), 205-228.

Zeichner, K. (2006). Reflections of a university-based teacher educator on the future of college- and university-based teacher education. Journal of Teacher Education, 57(3), 326-340.

Zeichner, K. (2007). Accumulating knowledge across self-studies in teacher education. Journal of Teacher Education, 58(36), 36-46.

Zeichner, K. M., \& Liston, D. P. (1996). Reflective teaching: An introduction. Mahwah, NJ: Erlbaum. 


\section{Appendix A Data Summary Themes}

\begin{tabular}{|c|c|c|}
\hline Self-Study Area & Degree of Change & Dynamics of Change \\
\hline Overall Program Quality & $\begin{array}{l}\text { About half of faculty believe } \\
\text { that the quality of student } \\
\text { preparation has improved. }\end{array}$ & $\begin{array}{l}\text { Those ambivalent in } 2012 \\
\text { expressed stronger opinions in } \\
2013 \text {. }\end{array}$ \\
\hline Coursework Planning & $\begin{array}{l}\text { About half of faculty agreed that } \\
\text { their approach to coursework } \\
\text { planning had changed. }\end{array}$ & $\begin{array}{l}\text { Opinions were stable across time } \\
\text { and consistent across faculty } \\
\text { subgroups. }\end{array}$ \\
\hline Assessment & $\begin{array}{l}\text { About a third of faculty } \\
\text { agreed that their approach to } \\
\text { assessment had changed and } \\
\text { nearly half of faculty agreed } \\
\text { that they have confidence in } \\
\text { the measures used to assess } \\
\text { program quality. }\end{array}$ & $\begin{array}{l}\text { Opinions were stable across time } \\
\text { and consistent across faculty } \\
\text { subgroups. }\end{array}$ \\
\hline Teaching Practices & $\begin{array}{l}\text { About a third of faculty agreed } \\
\text { that their approach to teaching } \\
\text { practices had changed. }\end{array}$ & $\begin{array}{l}\text { Clinical faculty were significantly } \\
\text { more likely to have changed than } \\
\text { tenure-track faculty in } 2012 \text { and } \\
2014 \text {. }\end{array}$ \\
\hline Approach to Curriculum & $\begin{array}{l}\text { About a third of faculty } \\
\text { agreed that their approach to } \\
\text { curriculum had changed. }\end{array}$ & $\begin{array}{l}\text { Clinical faculty were significantly } \\
\text { more likely to have changed than } \\
\text { tenure-track faculty in } 2012 \text {. }\end{array}$ \\
\hline Collaboration & $\begin{array}{l}\text { About half of faculty agreed that } \\
\text { collaboration had changed. }\end{array}$ & $\begin{array}{l}\text { Faculty observed a change in } \\
\text { collaboration more immediately } \\
\text { than in other self-study areas. }\end{array}$ \\
\hline Reflection & $\begin{array}{l}\text { About a third of faculty } \\
\text { members agreed that their } \\
\text { reflective practices had changed } \\
\text { in } 2012 \text {, increasing to more than } \\
\text { half in } 2013 \text {. }\end{array}$ & $\begin{array}{l}\text { Those ambivalent in } 2012 \\
\text { expressed stronger opinions in } \\
2013 \text {. }\end{array}$ \\
\hline $\begin{array}{l}\text { Awareness of local and national } \\
\text { discussions about accreditation }\end{array}$ & $\begin{array}{l}\text { About a third of faculty agreed } \\
\text { that their awareness levels had } \\
\text { changed. }\end{array}$ & $\begin{array}{l}\text { Faculty members were more } \\
\text { aware of conversations about } \\
\text { accreditation in } 2012 \text { than in } 2013 .\end{array}$ \\
\hline
\end{tabular}




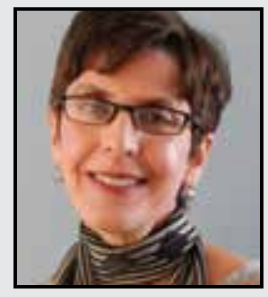

Mary D. Burbank is the Assistant Dean for Teacher Education and Director of the Urban Institute for Teacher Education (UITE) and oversees accreditation compliance in the College of Education at the University of Utah. In addition, she works with secondary preservice teachers where her teaching, research, and service interests identify pathways to higher education for under-represented students. She is the author/co-author of numerous books, chapters, and research articles and has secured over one million dollars in federal and state grants. Current projects include interdisciplinary linkages between University of Utah Colleges, Salt Lake Community College, and local school districts.

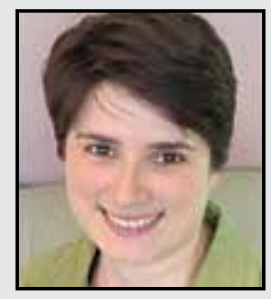

Melissa M. Goldsmith is a Research Analyst at the Urban Institute for Teacher Education in the College of Education at the University of Utah. She has a PhD in Political Science from the University of Utah and a master's degree in survey research from the University of Connecticut. She applies her knowledge of survey methods and data analysis for the purposes of improving program outcomes and meeting accreditation standards for the Teacher Education Licensure Program at the University of Utah.

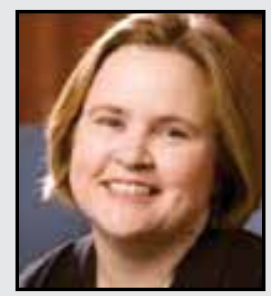

Alisa Bates is the Associate Director of M.Ed Programs and a faculty member teaching in the M.Ed programs. Prior to coming to Concordia University in 2014, Dr. Bates was an Associate Professor and the Director of the Online MAT program at Willamette University and an assistant professor at the University of Utah. Her scholarly agenda includes work in university supervision of field experiences, teacher research and inquiry, as well as effective online learning practices. Dr. Bates is driven by her commitment to high-quality, intellectual professional experiences for pre-service and inservice teachers, empowering them in their roles as educated professionals.

\section{LINK TO:}

http://uite.utah.edu/profile.php?unid=u0033947 